\title{
Prospects for the development of modern interstate legal systems in the context of globalization challenges
}

\section{Перспективи розвитку сучасних міждержавних правових систем в контексті глобалізаційних викликів}

Received: April 5, 2021
Accepted: May 8, 2021

Written by:

Lyudmyla Luts ${ }^{88}$

https://orcid.org/0000-0002-8182-2449

Iryna Nastasiak ${ }^{89}$

https://orcid.org/0000-0002-3963-1788

Catherine Karmazina ${ }^{90}$

https://orcid.org/0000-0002-6277-6889

Stepan Kovbasiuk ${ }^{91}$

https://orcid.org/0000-0002-6511-9286

\section{Анотація}

Перед людством постали нові цивілізаційні проблеми (управління загальносвітовими процесами, безпеки довкілля, охорони здоров'я, та ін). Важлива роль у їх розв'язанні відводиться міжнародним організаціям, міждержавним правовим системам. Аналіз дій щодо розв'язання глобальних проблем ставить перед правовою наукою питання про реальні можливості міжнародних організацій, міждержавних правових систем, про їхню здатність адекватно реагувати на глобалізаційні виклики, про необхідність 3'ясування їх ролі у новій реальності, а також про їх природу, форму, значущість. Йдеться про нову модель взаємодії держав у межах міжнародної системи, яка могла б забезпечити не лише їхнє співробітництво, а й інтеграцію завдяки новому інституційному механізму та системі правових актів. У дослідженні використані універсальні та європейські міжнародно-правові акти (зокрема, джерела права) та інші документи, які дозволяють запропонувати характеристику їх природи, форми, значущості, можливостей адекватно реагувати на глобалізаційні виклики сучасності. Основними у процесі дослідження стали: глобалізаційний підхід, логічні прийоми, загальнотеоретична, соціологічна, порівняльно-правова та міжнародно-правова методологія. Аналіз положень міжнародної,

\footnotetext{
${ }^{88}$ Doctor of Legal Sciences, Professor of the Department of Theory and Philosophy of Law of Ivan Franko National University of Lviv, Ukraine.

${ }^{89}$ Ph.D., Associate Professor of the Department of Theory and Philosophy of Law of Ivan Franko National University of Lviv, Ukraine.

${ }^{90}$ Ph.D., Associate Professor, Associate Professor of the Department of Constitutional Law and Justice, Odesa I.I. Mechnikov National University; attorney at law; Secretary of Odessa Bar Council, Ukraine.

${ }^{91}$ Senior lecturer of the Department of General Theoretical Jurisprudence of National University "Odessa Law Academy”, Ukraine.
} 
functioning of sovereign states and their cooperation. After the Second World War, those were formed that are designed to ensure closer cooperation based on universal and regional cooperation (United Nations, Council of Europe, European Union). New world order and interstate legal systems are being formed, which structure it. Their forms of integration are emerging, such as the legal system of the European Union. These systems have successfully fulfilled their role in streamlining the regional (European) and universal space. Although new globalization challenges of socioeconomic, security, information, health, and environment necessitated the formation of a new model of interstate legal systems, which would ensure not only cooperation but also integration, through the creation of a new institutional mechanism and an effective system of legal acts.

Keywords: globalization, international law, interstate legal systems, international organizations, interaction. зарубіжної та української правової науки, джерел права та юридичної практики дав змогу констатувати, що сучасні міжнародні організації виникли у зв'язку з необхідністю забезпечення функціонування суверенних держав та їх співробітництва. Після Другої світової війни утворилися ті 3 них, які покликані забезпечити тіснішу взаємодію на засадах універсального та регіонального співробітництва (Організація Об'єднаних Націй, Рада Європи, Європейський Союз). Формується новий світопорядок та міждержавні правові системи, які його структурують. 3'являються їх інтеграційні форми, як-от правова система Свропейського Союзу. Ці системи успішно виконали свою роль щодо впорядкування регіонального (європейського) та універсального простору. Але нові глобалізаційні виклики соціальноекономічного, безпекового, інформаційного характеру, охорони здоров'я та довкілля зумовили потребу у формування нової моделі міждержавних правових систем, яка б забезпечила не лише співробітництво, а й інтеграцію, завдяки створенню нового інституційного механізму та ефективної системи правових актів.

Ключові слова: глобалізація, міжнародне право, міждержавні правові системи, міжнародні організації, взаємодія.

\section{Introduction}

The formation in the second half of the twentieth century of a new model of international organizations (formed to ensure the functioning of states and cooperation) is based on the principles of international peace and security, cooperation of states.

Today, there are a large number of international organizations that operate following the principles set out in the United Nations Charter (1945a). Interstate legal systems are being created that ensure the structuring of the social space and the formation of the world community for a long time. It is up to them to solve the problems that the state has not been able to solve on its own. By the end of the twentieth century, they developed especially intensively in Europe, a new form of integration appeared - the legal system of the European Union. However, the tendency to create such forms can be traced in other regions of the world.

For a long time, they responded appropriately to the problems that arose in the process of human development. The current stage of human development is characterized by new global challenges: political, socio-economic, without a pitch, information, environmental, health, etc. They have become a test of the effectiveness of interstate legal systems, their legal means, the possibility of prompt resolution of problems based on norms and principles of international law, coordination of actions of member states. They also necessitated the formation of a new model of interstate legal systems, which would ensure not only the cooperation of states but also their integration, through the creation of a new institutional mechanism and an effective system of legal acts.

In this context, it seems necessary to "audit" the existing large number of international organizations and their ability to perform tasks following the norms and principles of international law, their compliance with modern realities, and the ability to meet human needs under new realities.

The international legal doctrine also needs to be revised, which should offer a new conceptual 


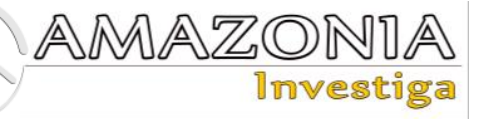

vision of interstate legal systems, international organizations, international law in the context of compliance with the general legal framework, which would be the basis for the formation of an effective international legal system. This would create models of concerted behavior, record common ways of interacting, means of communication, and guarantee the implementation of the principles and norms of international law.

The institutional and functional parts of interstate legal systems also need to be revised, which would create a new form of international law that would be able to respond effectively to global changes that will be characteristic not only of modern but also of further stages of human development.

The purpose of the study is to find a new organizational and legal model of interaction between states within the international system, which could ensure their cooperation and integration.

\section{Theoretical Framework or Literature Review}

The emergence of intergovernmental organizations in the early XIX century, which became the prototype of their modern analogies of the late XIX - early XX centuries, was due to the need to create a form that would ensure the functioning of sovereign states and their cooperation. This form became administrative unions (the International Union for the Measurement of Land in 1864, etc.), which ensured the cooperation of states in particular areas and, at the same time, contributed to the institutionalization of the world community.

In 1945, the United Nations was established to ensure the integration of states in both political and socio-economic issues (United Nations, 2021). The Preamble to the United Nations Charter (1945a) states that an international organization called the United Nations is formed to achieve the following objectives: to maintain international peace and security; to ensure the development of friendly relations between nations; to ensure international cooperation in solving international problems of economic, social, cultural, humanistic nature in the development of respect for human rights and fundamental freedoms; to be the center of coordination of actions of nations in the achievement of these basic purposes.

Art. 2 of the Vienna Convention on the Law of Treaties (United Nations, 1969) states that the term "international organization" means an intergovernmental organization. There is no uniform understanding of the international organization in the international legal literature, and the attempts of the United Nations Commission on International Law to create a legal definition have not been successful (Conforti, 2004). However, despite the many classification criteria and selected types of international organizations, the criterion of membership can be distinguished: interstate (intergovernmental) organizations - the founders of which are states, and international (nongovernmental) - the founders of which are individuals, legal entities and other entities (Lindblom, 2006). With regard to international non-governmental organizations, reference should be made to United Nations Economic and Social Council Resolution 288 (X) of 27 February 1950, which states that any international organization not established under an international agreement must have considered as a non-governmental organization (Schermers, \& Blokker, 2011).

However, in the international-legal literature, it is noted that in the modern system of international relations the leading role is played by interstate organizations (Grant, \& Barker, 2009). An intergovernmental organization usually has the following characteristics: the presence of member states endowed with international legal personality; constituent interstate agreement; permanent bodies; functioning following the principles and norms of international law.

According to the range of subjects (member states), intergovernmental organizations are divided into universal and regional, interregional. In the international legal literature in the late $\mathrm{XX}$ - early XXI centuries, it was noted that within the interstate forms is expanding the functions and powers of international organizations (Shestakov, 2009).

It is worth noting that at the end of the twentieth century, there was a question of the formation of a world community, which aims to address the common interests: the vital interests and values of all mankind (Morozov, 1986), solving its global problems. An objective factor in the formation of the world community is the rapprochement of states based on universal interests and values because without this they can not ensure a significant range of their important interests (Lukashuk, 2000).

The term "international community" is used to describe the world community after the adoption 
of the Charter of the United Nations, although the Charter uses only the terms "international organization", "United Nations" (United Nations, 1945a). And only in Art. 53 of the Vienna Convention on the Law of Treaties refers to the "international community of states" (United Nations, 1969).

Later, the terms "international system", "interstate system" began to be used. There are arguments about the need to distinguish between the concepts of "world community" (i.e. all participants in international communication) and the international community of states (subjects of which are only states) (Evintov, 1990).

\section{Materials and methods}

The purpose of the work is to analyze the international experience of modern universal and regional (in particular, European interstate legal systems) and prospects for their development in the context of new globalization challenges.

The study uses scientific legal sources, international legal acts (both universal and regional, including European), and other documents on the status and functioning of interstate legal systems, which allowed to characterize their nature, form, significance, ability to adequately respond to modern challenges.

To achieve this goal, a globalization approach was used, which allowed defining the strategy of studying universal and European interstate legal systems as a process of accelerating and expanding the relationship between the subjects of international law; logical techniques that accompanied the entire research process.

Thus, the general theoretical methodology made it possible to identify the main worldwide patterns of origin and functioning of modern interstate legal systems, to characterize their nature and structure.

The international-legal methodology has helped to identify structures typical of international relations, to solve universal and regional (including European) problems and forms that ensure their efficient solution.

Moreover, sociological methodology allowed to analyze international legal documents (the Charter of the United Nations, the Council of Europe, the Constituent Treaties of the European Union), to gather the information necessary to characterize these interstate legal systems.
Besides, comparative-legal methodology allowed to identify similar features of universal and regional, European interstate legal systems, which allowed to consider them as components of the international system as a whole, to identify the features of each of them.

\section{Results and Discussion} The role of interstate legal systems in the
structuring of the world social space

The concept of the interstate legal system is formed - a holistic structurally organized with the help of international law and other means of sustainable interaction of international law, which provides international law as a necessary prerequisite for the functioning of the world system in general and its regional systems in particular (Luts, 2003). The interstate legal system consists of institutional (subjects of international law), functional (relationships between these subjects), normative (international-legal means) parts, the features of which form an identification code. The following features are characteristic of interstate legal systems: they function following generally accepted international legal norms and principles within the limits set by the constituent treaties; they are formed by subjects of international law (first of all, states); due to the activities of these entities, there are permanent ties between them (international legal relations); their regulation is ensured by international-legal means; the functioning of such systems is aimed at achieving international law (Luts, 2003). According to the range of subjects and their status, interstate legal systems are divided into universal (United Nations) and regional (European, American, etc.).

The emergence of interstate legal systems was due to changes in global infrastructure, the formation of global and regional social systems under the influence of globalization and regionalization, as well as the following objective factors: increasing the number of subjects of international legal relations, their complexity; recognition of several global issues; the need to change international legal regulation, the growing role of legal remedies in the settlement of international relations. It was the interstate legal systems that were responsible for solving problems that states were unable to resolve by their legal means. Such legal systems played an important role in structuring the universal and regional social space. 


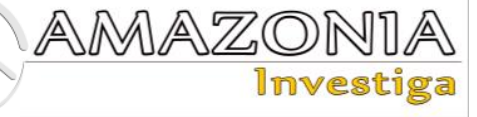

In the second half of the twentieth century, objective preconditions for the formation of such systems existed, first of all, in Europe, although, the tendencies to their creation were observed in other regions of the world. This was related to the concept of integration, which replaced the concept of "international cooperation", and which means going beyond it to the formation of a single structure.

An essential role in the formation of the European social space in this period is given to the legal systems of the Council of Europe and the European Union. The Council of Europe is indeed based on the principles of cooperation, like any other international organization but the legal mechanism for the protection of human rights and fundamental freedoms plays a significant role in shaping its legal system. After all, it creates universal means of settling relations for member states. Thus, for the Council of Europe it is the existence of a convention body the European Court of Human Rights; creation by them of law-enforcement and law-interpreting precedents which are necessary for unification of judicial practice by the participating states; formation of legal standards - common European legal requirements for member states within the European legal space, enshrined in the sources of law of the Council of Europe and other legal acts. Within the legal system of the Council of Europe, a member state develops a national legal system following European legal standards, and, thus, creates the preconditions for entering a more complex form - the legal system of the European Union. A great feature of this legal system is the high level of legal unification, the availability of effective means of regulatory integration. It should be noted, that the legal system of the European Union is quite flexible, and, therefore, its transformation is taking place in the context of modern changes, albeit with overcoming significant obstacles.

Thus, its modernization within the framework of the Treaty establishing a Constitution for Europe (European Union, 2003) was conditioned by the need to solve the global problems of that period of development of the European region by legal means and means, but with the main priorities, including the unification of Europe (European Union, 2003).

However, it is necessary to state the attempts to change the nature of the interstate legal system by developing properties that are not inherent in it (excessive enthusiasm for the formation of some institutions on the model of nation-states; use of attributes inherent in states; substitution of concepts, such as the Treaty establishing a Constitution for Europe is identified with the Constitution, etc; propaganda of the development trends of the European Union as a "supranational" or "federal" organization, although its nature testifies to the international character, although with a high level of integration properties) led to the failure of ratification of this Treaty by member states.

This need for change led to the emergence of a new treaty - the Lisbon Treaty (European Union, 2007) (Treaty amending the Treaty on European Union and the Treaty on the Functioning of the European Union), which took into account the positive provisions of the Treaty establishing a Constitution for Europe, amended contradictory provisions, was ratified and entered into force 01 December 2009. The Preamble to the Lisbon Treaty states that the agreement is a confirmation of a new stage of European integration and aims to ensure universal values, a stable foundation for the future of Europe, the convergence of economic systems, etc. At the same time, paragraph 5 of Art. Article 3 of the Lisbon Treaty (European Union, 2007) (Article 2 of the previous Treaty) states that, together with the Member States, the Union shall promote peace, security, sustainable development, strict observance, and development of international law, in particular the principles of the United Nations Charter (1945).

To achieve the goals of both universal and regional interstate legal systems, each of them forms a system of legal acts, a significant component of which is the system of sources of law. First of all, you should refer to Art. 38 of the Charter of the International Court of Justice of the United Nations, which legalizes the list and nature of sources of international law: international conventions (general and special), establishing rules recognized by the parties to the dispute; international custom as a proof of general practice recognized as a legal norm; general principles of law recognized by civilized nations; with a limitation to Art. 59, court decisions and doctrines of the most qualified specialists in the public law of different nations as an additional tool for determining legal norms (United Nations, 1945b).

A corresponding position on international treaties and customary international law is also expressed in the Vienna Convention (United Nations, 1969), which enshrines the provisions on the recognition of the growing importance of treaties as a source of international law; due regard to the principles of international law 
enshrined in the Charter of the United Nations; the effectiveness of customary international law, which are not reflected in the Convention.

In Art. 1 of the Statute of the Council of Europe (1949) explicitly states that the aim of the Council of Europe is achieved through its bodies through the discussion of issues of common interest and the conclusion of agreements and joint actions in the economic, social, cultural, scientific, legal and administrative fields, as well as areas of protection, preservation and further implementation of human rights and fundamental freedoms.

To ensure its objectives, the European Union has set up the following mechanism: the European Parliament, the European Commission, the European Council, the European Court of Justice, the Council of the European Union, the European Central Bank, the European Court of Auditors (European Union, 2007), and the legal system: Treaty on the Functioning of the European Union); international agreements with third countries or international organizations (Article 216 of the Lisbon Treaty (European Union, 2007)), legal acts of the institutions of the Union (regulations, directives, decisions, recommendations, conclusions).

According to Art. 288 of the Treaty on the Functioning of the European Union, the regulation is binding, general, and directly effective in all member states; directives are binding on the outcome, but national authorities have a choice of form and means; decisions are binding in full; recommendations and conclusions are not mandatory (European Union, 2016). And Art. 289 of the Treaty on the Functioning of the European Union provides for the adoption of legislative acts (jointly by the European Parliament and the Council of regulations, directives, decisions) or under a proper legislative procedure (European Union, 2016).

If the international situation requires prompt action by the Union, the Council shall take the necessary decisions. In the event of a change in the conditions that have a significant impact on the issues that are the subject of such decisions, the Council reviews the principles and objectives of this decision and adopts the necessary decisions (Article 28 of the Treaty on European Union) (European Union, 1992).

According to Art. 220 of the Treaty on the Functioning of the European Union establishes all appropriate forms of cooperation with the
United Nations and its specialized agencies, the Council of Europe, the Organization for Security and Cooperation in Europe, the Organization for Economic Co-operation and Development; maintains proper relations with other international organizations (European Union, 2016). The Court of Justice of the European Union has jurisdiction to apply and interpret sources of European Union law. This indicates the existence of an effective system of legal remedies, the purpose of which is to settle the relevant relations, to respond promptly to various challenges.

Such a sample analysis of interstate legal systems shows that at the time of their creation and for a long time, they generally effectively addressed the problems that arose in the process of human development, responded appropriately to challenges of both global and regional (including European) scale.

\section{Globalization challenges of today}

The current state of human development is characterized by new, much more complex challenges. Under the influence of globalization, humanity has become a holistic system that has created unlimited possibilities, but at the same time has created several new problems that need to be addressed urgently. Globalization is an objective process of human development in the context of the formation of the world social system, the subsystem of which is the interstate legal systems (both universal and regional).

Globalization is a continuous (Enshina, 2016), multidimensional process (Mikalauskiene, Streimikiene, \& Mulagalejeva, 2016) of environmental transformation (created by both international and national institutions) by a powerful and objectively mediated factor (Marquis, Yin, \& Yang, 2017).

Although currently there are no clear criteria for distinguishing the main dimensions of globalization, characterizing the levels of interaction (international, regional, etc.) that occur in the process of globalization called the following areas of influence: economic, political, cultural, religious, military (Cuterela, 2012); legal (Sopilko, 2020); social, economic, political, technological (Mikalauskiene, Streimikiene, \& Mulagalejeva, 2016); economic, political, security (Göksel, 2004).

There is an attempt to classify the problems of globalization, in particular, as follows: universal difficulties of political and socio-economic, 


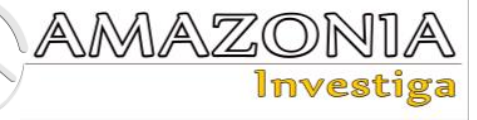

natural-economic, social, environmental, informational, technological, scientificintellectual, mixed-nature (Belous, 2002). The priority among them is the global problem of sustainable development of the world (in particular, the issue of global governance). However, no less significant are other issues, such as energy, food, environmental, raw materials, demographic, international, health, religion, etc. (Belous, 2002)

These and other issues in recent decades are under constant scientific attention, attempts to systematically study the processes of globalization, identify problems and possible ways to prevent or overcome them; features of the development of modern legal systems in the context of globalization and transformation (Sopilko, 2020).

Of course, a vital role in solving global problems was given to international organizations, interstate legal systems, and in the communiqué of the heads of state and government of the G8 countries in 1999, the position of the respective states was expressed on the preservation and enhancement of globalization to them people all over the world, as well as a call to states, international organizations, business circles, civil society, individuals to jointly solve global problems (G7 Informational Center, 2001). The formation of institutional structures, a system of legal means that would ensure the solution of such problems was obvious.

The 1920s made new adjustments to the tasks of international organizations, interstate legal systems and became a kind of test of their ability to meet new globalization challenges. And such challenges, which can only be overcome through joint efforts, have included the effectiveness of the health care system (due to the worldwide pandemic).

The value of human life, human health in the context of the relevant rights to fundamental rights enshrined in the International Covenant on Civil and Political Rights of 1966, the Convention for the Protection of Human Rights and Fundamental Freedoms of 1950, and the Charter of Fundamental Rights of the European Union of 2000. The relevant rights to life, health, safe environment, etc. have become not declarative provisions, but objects that require immediate exceptional terms under close cooperation of both states and international organizations (universal and regional levels).
Current global challenges include the prospects for the development of the modern world economy (after all, it is still based on trust and confidence in the future, as well as any interaction at the international level is based on cooperation); environmental protection, health care, etc. These and other challenges (including the spread of the new virus) have revealed the unwillingness of States and intergovernmental organizations to respond appropriately; lack of useful tools, strategies for solving relevant problems.

All this raises the question of legal science about the real possibilities of modern interstate legal systems to provide new globalization challenges. After all, modern international organizations, interstate legal systems were formed based on the idea of cooperation of states, which is enshrined in major international legal instruments (both universal and regional), which was relevant and effective and formed the basis of interaction between states after World War II. But the problems of the beginning of the XXI century require the formation of new approaches to understanding the nature and nature of such international organizations and interstate legal systems.

\section{Prospects for the development of modern interstate legal systems}

The current state of development of the world order and the global challenges that accompany it require a different model of interaction between states within the international system. And such a model should ensure not only cooperation but also their appropriate integration. This model should be based on the principles of closer cooperation between the member states and have a proper institutional mechanism and regulatory framework that would ensure the settlement of relations in the relevant areas defined by the founding treaties.

Although international law has not proposed a new concept of world order, the challenges of globalization, including the rapid spread of the new virus, the lack of adequate national health systems, information and communication systems, have called into question the highest value of human life. This could be evidence of the declarative provisions of international covenants, the European Convention and other legal instruments, the ineffectiveness of the system of international legal regulation, as well as interstate legal systems in general. Or it was necessary to draw the attention of representatives of legal science, subjects of international legal 
relations, to the need to revise the doctrines of international relations and international law.

Equally important are security issues, the mechanism of which is based on the principles set out in the Declaration of Principles of International Law on Friendly Relations and Cooperation between States (United Nations, 1970), the provisions of which are aimed at ensuring the purpose of the United Nations peacekeeping and security and the development of friendly relations and cooperation between states, including the principles of refraining from the threat or use of force against the territorial integrity or political independence of any state, as well as the Declaration on Intervention and Interference in the Internal Affairs of States (United Nations, 1981) the obligations of the state to refrain from the threat or use of force; refrain from any action or in any form destabilize or undermine the stability of another state.

Modern realities show significant violations of the principles of international law and the lack of appropriate response of the international community to effective legal means that would ensure their implementation. This turns the relevant legal requirements of international legal documents into declarative provisions (wish lists), if the possibility of their provision is not used, or into legal fictions (when non-existent is declared existing). These circumstances necessitate the revision of the entire system of legal regulation, the creation of effective and efficient remedies that will effectively ensure legal regulation or international legal order in general.

Given the above, it should be noted that for the period of formation and renewal of modern interstate legal systems (in the 50s and until the end of the twentieth century), they corresponded to the conceptual provisions and the nature of the essence of international law; ensured observance of the principles of peaceful coexistence and cooperation of states. However, in the context of modern change, international organizations should be "audited" and fulfill their obligations following the principles of international law and the current needs of human development.

Thus, there have been many recent statements about the need to reform the World Health Organization. An analysis of the Constitution of the World Health Organization gives grounds to state the existence of a significant number of declarative prescriptions, in particular in Art. 1 states that the goal of the World Health Organization is to achieve the highest possible level of health for all peoples, etc. (World Health Organization, 1946). As for Art. 2 of the Constitution (World Health Organization, 1946), its provisions contain a significant number of obligations of this international organization: to act as a governing and coordinating body in international health work; provide and maintain such administrative and technical services, including epidemiological and statistical, as may be required; to develop work in the fight against epidemiological and other diseases; research in the field of health care; to study with specialized institutions issues of administrative and social life that affect medical care in terms of their preventive and curative value, including hospital care and social security; conduct research in the field of health care, etc.

However, with the rapid spread of the new virus, the World Health Organization has failed to meet its responsibilities. Not only has this been criticized for its lack of coordination, but it has also created several obstacles to the proper use of health care tools.

And the doctrine of international law, in general, needs to be revised in terms of compliance of international law with common law (general theoretical and logical) requirements, namely: the system of international legal regulation must be determined by the objective needs of mankind; principles, norms and other international legal means must ensure the regulation of existing relations; their system must be holistic and stable, flexible (timely change of internal structure), effectively respond to the real needs of legal entities.

This design should be more efficient due to the ability to adapt to the requirements of the time. It would make it possible to create models of concerted behavior that both international organizations and states will be called upon to ensure; to fix standard ways of interaction, conditions of preservation and rupture of communications between subjects of the right, means of maintenance of the integrity of the system, guarantees of realization of principles and norms of the international law, etc.

Not only the normative part of interstate legal systems needs to be revised, but also the institutional and functional ones. The institutional part should be formed in such a way that it is effective (not overloaded with a large number of structural units, a large number of employees who must be professionals who respond quickly to the situation, etc.). This will help to avoid conservatism and bureaucracy, and 


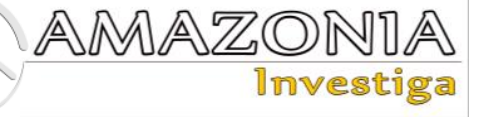

thus remove obstacles to the proper functioning of the international organization, its implementation of the rules and principles of law.

The COVID-19 Pandemic is associated with an unprecedented narrowing of human rights and freedoms around the world (Tkalych, Safonchyk, $\&$ Tolmachevska, 2020). Since the pandemic in the social sense is a challenge to society as a whole and each individual, it exacerbates the conflict of public and private interests: if the individual cares primarily about himself, the community - about itself as a system (Kharytonov, Kharytonova, Kolodin, \& Tkalych, 2020).

As an example of responding to the challenges of time to ensure the COVID-19 pandemic, the European Court of Human Rights decided to approve the Court's instructions from March 16, 2020, till June 15, 2020. The Court was transferred to teleworking (Unified Contact Center of the Judiciary of Ukraine, 2020). At the same time, although the implementation of the principles of justice in a pandemic was difficult, it led to the introduction of innovative measures, wider use of IT technologies in the judiciary, including the formation of "cyber justice" (Horodovenko, Bondar, \& Udovyka, 2021). Besides, it should be noted, that Ukraine is moving towards the harmonization of its legislation with the legal framework and the recommended EU standards (Pavlova, Polunina, Tkalych, Mankovskyi, \& Zubair, 2020).

All this is evidence of the need for transformations of the international world system, and, in particular, interstate legal systems.

\section{Conclusions}

Analysis of the provisions of international, foreign and Ukrainian legal science, sources of law and other legal acts gives grounds to draw a number of conclusions: interstate legal systems once became an objectively necessary form of ensuring the functioning of sovereign states and their cooperation in specific fields; modern international organizations that ensured close cooperation between states in political and socioeconomic issues emerged after the Second World War (United Nations, Council of Europe, European Community, Euratom and Eurocoal); at the end of the twentieth century, a "world community" is formed, the purpose of which is to ensure the vital interests and values of all mankind, and which is referred to as the international system; the concept of interstate legal system is formed as a stable interaction of subjects of international law, which ensures a proper international legal order; according to the range of subjects and status, universal and regional, in particular, European ones are distinguished among them.

Their emergence is due to changes in the world order under the influence of globalization challenges of the late twentieth century (ensuring the peaceful coexistence of states, the threat of nuclear war, etc.), as well as other factors such as increasing the number of subjects of international law, complicating international relations.

Interstate legal systems are responsible for solving such problems that the state could not overcome by its means, in particular, the structuring of universal and regional social space. A system of useful sources of law should help to solve these problems.

Objective preconditions for the formation of new, integrative forms of interstate legal systems emerged in Europe in the second half of the twentieth century, when the concept of "international cooperation" was replaced by the notion of "integration". The legal systems of the Council of Europe and the European Union play a significant role in these processes.

For the Council of Europe's legal system, the jurisdictional mechanism for the protection of human rights and fundamental freedoms (the European Court of Human Rights) and the sources of Council of Europe law, which form the legal standards for member states, are integrative.

A feature of the legal system of the European Union is the high level of legal unification, the availability of effective means of regulatory integration. It is quite flexible, its transformation takes place in the context of modern change. In 2007, a new Constituent Treaty of the European Union was concluded - the International Agreement (consisting of the Treaty on European Union and the Treaty on the Functioning of the European Union), which entered into force in 2009. The Preamble to this document states that it is a confirmation of a new stage of European integration.

The legal system of the European Union is characterized by an institutional mechanism, the feature of which is the creation by the European Parliament and the Council of legal acts that are binding on the member states. In general, the 
legal system of the European Union has a system of legal acts, that effectively regulates relations and promptly responds to functional changes.

Until recently, intergovernmental legal systems were generally successful in solving problems of a universal and regional nature, and even global problems. Today is identified by new globalization challenges: economic, political, social, informational, military, and others. Particular attention is paid to the problem of sustainable development of mankind. International organizations, in particular, intergovernmental legal systems, play an important role in solving these problems. Their internal organization is formed from the relevant institutions and systems of legal means that would ensure the solution of new problems.

The 1920s became a test for interstate legal systems, and adjustments were made to their form, structure, and tasks.

The new globalization challenges are a "litmus test" for checking the effectiveness of management, rapid response to existing problems, the availability of an appropriate system of legal remedies. These include global economic development, health (COVID-19 pandemic), security (terrorism, hybrid wars, cyber wars), and more. It should be noted that neither states nor interstate legal systems have always been able to resolve them effectively and expeditiously based on norms and principles of international law. And this raised before legal science the question of the real possibilities of interstate legal systems, their ability to adequately respond to globalization challenges. It is obvious that the interstate legal systems, which were formed 70 years ago based on international cooperation, were effective for their time. But as the world order changes under the influence of new globalization challenges, they need a new vision of their role, significance, nature, form, etc.

First of all, it is a new model of interaction between states within the international system. And such a model should ensure not only their cooperation but also integration. This requires the formation of another institutional mechanism and regulatory framework and the system of legal acts in general. Otherwise, it may call into question the legal provisions enshrined in the system of sources of international law, recognize them as a "catalog of wishes", which is not provided with appropriate guarantees. In addition, it is necessary to conduct an "audit" of international organizations (as to the need for such a number of them), their compliance with their obligations following the rules and principles of international law; to test their effectiveness in the context of the needs of the current stage of human development.

It is necessary to remember that international legal doctrine also needs to be revised in the light of established law constructions. It should correspond to the idea of the legal system (regulatory system); would allow to create the models of coordinated behavior, fix standard ways of interaction, means of maintenance of communications between subjects of the right, guarantees of realization of principles and norms of the international law.

The institutional and functional parts of the legal systems also need to be reviewed, which will allow us to take the first steps towards creating new international legal forms that will be able to respond effectively to the global changes that objectively accompany the current stage of human development.

\section{Bibliographic references}

Belous, O. (Ed.). (2002). Globalization and security of development. Kyiv: Kyiv National University of Economics.

Conforti, B. (2004). The Law and Practice of The United Nations (Legal Aspects of International Organization). Leiden/Boston: Martinus Nijhoff Publishers.

Council of Europe. (1949). Statute. Recovered from https://www.coe.int/en/web/conventions/full-list//conventions/treaty/001.

Cuterela, S. (2012). Globalization: Definition, Processes and Concepts. Romanian Statistical Review Supplement, Romanian Statistical Review, 60(4), 137-146. Recovered from https://ideas.repec.org/a/rsr/supplm/v60y2012i4p1 37-146.html.

Enshina, E. (2016). Globalization process in modern word. Historical and social-educational ideas, 1 , 108-110. DOI: 10/17748/2075$9908=2016-8-3 / 1-108-110$.

European Union. (1992). Treaty. Recovered from https://europa.eu/european-

union/sites/default/files/docs/body/treaty_on_euro pean_union_en.pdf

European Union. (2000). Charter of Fundamental Rights of the European Union. Recovered from https://eur-lex.europa.eu/legal-

content/EN/TXT/?uri=celex\%3A12012P\%2FTXT

European Union. (2003). Draft Treaty establishing a Constitution for Europe. Recovered from https://eur-lex.europa.eu/legalcontent/EN/TXT/?uri=CELEX\%3A52003XX0718 $\% 2801 \% 29$

European Union. (2007). Treaty of Lisbon, amending the Treaty on European Union and the 


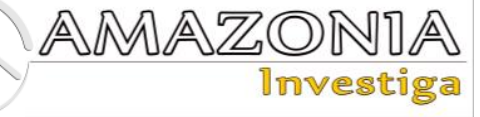

Treaty establishing the European Community (2007 / C 306/01). Recovered from https://eurlex.europa.eu/legalcontent/EN/TXT/?uri=celex\%3A12007L\%2FTXT European Union. (2016). Consolidated versions of the Treaty on European Union and of the Treaty on the Functioning of the European Union with protocols and declarations. https://eurlex.europa.eu/legalcontent/EN/TXT/?uri=celex\%3A12016ME\%2FT

\section{XT}

Evintov, V.I. (1990). International community and law and order. Kyiv: Naukova Dumka.

G7 Informational Center. (2001). Communique of the Heads of State and Government of the G8. Recovered from http://www.g7.utoronto.ca/summit/2001genoa/fina lcommunique.html

Göksel, N. (2004). Globalization and the State. PERCEPTIONS. Journal of International Affairs, 9(1), 1-12.

Grant, P.J., \& Barker, J.C. (2009). Encyclopaedic Dictionary of International Law. Oxford: Oxford UniversityPress.

Horodovenko, V., Bondar, O., \& Udovyka, L. (2021). Jastice in the Covid-19 era Throughthe Prism of Judicial Power. Ius Humani Law Jounal, 10(1), 51-7. Recovered from http://www.iushumani.org/index.php/iushumani/is sue/view/11.

Kharytonov, E., Kharytonova, O., Kolodin, D., \& Tkalych, M. (2020). The Covid-19 Pandemic and the Rights of the Individual in Terms of Private and Public Law. Ius Humani. Law Journal, 9(2), 225250. Recovered from https://doi.org/https://doi.org/10.31207/ih.v9i2.253 Lindblom, A.-K. (2006). Non-Governmental Organizations in International Law. Cambridge: Cambridge University Press.

Lukashuk, I.I. (2000). Globalization, state and law, XXI century. Moscow: Spark.

Luts, L.A. (2003). European interstate legal systems and problems of integration with them of the legal system of Ukraine (theoretical aspects). Kyiv: Osnova.

Marquis, C., Yin, J., \& Yang, D. (2017). StateMediated Globalization Processes and the Adoption of Corporate Social Responsibility Reporting in China. Management and Organization Review, 13(1), 167-191. DOI: 10.1017/mor.2016.55.

Mikalauskiene, A., Streimikiene, D., \& Mulagalejeva, K. (2016). Assess the Impact of Globalisation Processes by Indices. Economics and Sociology, 9(4), 82-100. DOI: 10.14254/2071789X.2016/9-4/5.

Pavlova, Y., Polunina, O., Tkalych, M., Mankovskyi, V., \& Zubair, A. (2020).
International-legal standards of cooperation of ukraine in the field of environmental (climate) problems. Amazonia Investiga, 9(25), 295-301. https://amazoniainvestiga.info/index.php/amazonia /article/view/1069

Schermers, H.G., \& Blokker, N.M. (2011). International Institutional Law Unity within Diversity. Leiden \& Boston: Martinus Nijhoff Publishers.

Tkalych, M., Safonchyk, O., \& Tolmachevska, Y. (2020). Private Law and human rights: New realities. DIXI, 22(2), 1-12. DOI: https://doi.org/10.16925/2357-5891.2020.02.04

Unified Contact Center of the Judiciary of Ukraine. (2020). A webinar on the network of ECtHR high courts on the administration of justice in a pandemic took place. Recovered from https://supreme.court.gov.ua/supreme/prescentr/news/968811/.

United Nations. (1945a). Charter. Recovered from https://www.un.org/en/about-us/un-charter/fulltext

United Nations. (1945b). Statute of the International Court of Justice. Recovered from https://www.icj-cij.org/en/statute

United Nations. (1950). Convention for the Protection of Human Rights and Fundamental Freedoms. Recovered from https://www.echr.coe.int/documents/convention_e ng.pdf

United Nations. (1966). International Covenant on Civil and Political Rights. Recovered from https://www.ohchr.org/en/professionalinterest/pag es/ccpr.aspx.

United Nations. (1969). Vienna Convention on the Law of Treaties. Recovered from. https://legal.un.org/ilc/texts/instruments/english/co nventions/1_1_1969.pdf

United Nations. (1970). The Declaration on Principles of International Law concerning Friendly Relations and Co-operation among States in accordance with the Charter of the United Nations. Recovered from https://www.un.org/ruleoflaw/files/3dda1f104.pdf United Nations. (1981). Declaration on the Inadmissibility of Intervention and Interference in the Internal Affairs of States. Recovered from https://digitallibrary.un.org/record/27066

United Nations. (2021). UN Official Web-Site. Recovered from https://www.un.org/en/about-un/. World Health Organization. (1946). Constitution. Recovered from https://www.who.int/governance/eb/who_constitut ion_en.pdf 